\title{
Potensi Ekstrak Biji Pangi (Pangium edule Reinw) sebagai Pengawet Alami Pada Ikan Mujair (Oreochromis mossambicus)
}

\section{Iren Natalia Simanjuntak, Rudi Alexander Repi, Emma Mauren Moko*, Meity Neltje Tanor, Debby Jacqueline Jochebed Rayer}

Biologi, Universitas Negeri Manado, Tondano, 95619, Indonesia

INFO ARTIKEL

Diterima 28 September 2020

Disetujui 30 Oktober 2020

Key word:
Pangi seed extract
tilapia fish
natural preservative
Cyanide
Toxicity
pH
protein

\section{Kata kunci:}

Ekstrak biji pangi

ikan mujair

pengawet alami

Sianida

Toksisitas

$\mathrm{pH}$

protein

\begin{abstract}
Mujair fish (Oreochromis mossambicus) is a freshwater fish that is commonly consumed. This is due that they are easily found and obtrained and with a price in fresh markets that are relatively cheap. Unfortunately, this fish happens to be a very perishable commodity, due to it's sensitiveness to spoilage because of its high protein content and moisture content. Pangi seeds (Pangium edule) is known to contain tanines, natural polyphenols that inhibits microorganisms through their cell wall permeability. The purpose of this research was to test the potential of pangi seeds crude extract as natural pangi seed toxiti preservatives on mujair fish, shelf life potential on mujair fish. This was achieved by marinating the fish in crude pangi seed extracts at concentrations of $0 \%$ (control), $5 \%$ and $10 \%$ and then store for 4 days at room temperature. Parameters tested on this research includes cyanide identification BSLT toxicity testing and fish spoilage (degradation) through protein changes and $p H$. Results of this research indicated that pangi seeds crude extract does not contain any cyanide of whatsoever, pangi seed crude extract toxicity testing indicated thatit was not toxic to a concentration of $128233 \mathrm{mg} / \mathrm{L}$, meanwhile protein analysis indicated that the optimum concentration of pangi seed crude extract to inhibit fish spoilage is $10 \%$ while in terms of $p H$ degradation, the optimum concentration was $5 \%$.
\end{abstract}

\section{A BSTRAK}

Ikan mujair (Oreochromis mossambicus) merupakan ikan yang hidup di air tawar, merupakan ikan yang sering dikonsumsi oleh masyarakat karena selain mudah didapat, harganya juga terjangkau akan tetapi merupakan jenis ikan yang mudah mengalami proses pembusukan karena mengandung protein dan air yang cukup tinggi. Biji pangi diketahui banyak mengandung tanin merupakan senyawa polifenol alami yang dapat menghambat pertumbuhan mikroba melalui permeabilitas dinding selnya. Tujuan penelitian ini untuk menguji potensi ekstrak biji pangi sebagai pengawet alami ikan mujair, mengetahui lamanya daya simpan pada proses pengawetan ikan mujair menggunakan ekstrak biji pangi dan mengetahui konsentrasi yang tepat dalam proses pengawetan ikan mujair. Metode penelitian dilakukan dengan merendam ikan pada ekstrak biji pangi konsentrasi $0 \%$ (kontrol), $5 \%$ dan 10\% yang disimpan selama 4 hari pada suhu kamar. Parameter lain yang di uji yaitu identifikasi sianida menggunakan berbagai pereaksi, uji toksisitas BSLT, tingkat kerusakan ikan melalui parameter perubahan protein dan $\mathrm{pH}$. Hasil penelitian menunjukkan ekstrak biji pangi sudah tidak mengandung sianida setelah diberikan perlakuan, uji toksisitas ekstrak biji pangi menunjukkan bahwa ekstrak biji pangi tidak toksik pada kosentrasi $128233 \mathrm{mg} / \mathrm{L}$, sedangkan hasil analisis protein menunjukkan bahwa konsentrasi pemberian ekstrak biji pangi paling optimal adalah konsentrasi $10 \%$ sedangkan hasil uji pH konsentrasi optimal adalah konsentrasi $5 \%$. *e-mail:

emmamoko@unima.ac.id 


\section{Pendahuluan}

Ikan mujair (Oreochromis mossambicus) merupakan ikan yang hidup di perairan Indonesia khususnya di air tawar. Ikan mujair merupakan ikan yang sering dikonsumsi oleh masyarakat karena selain mudah didapat, harganya juga terjangkau akan tetapi ikan mujair merupakan jenis ikan yang mudah mengalami proses pembusukan karena mengandung protein dan air yang cukup tinggi [1].

Kelemahan-kelemahan yang dimiliki oleh ikan mujair sangat berpengaruh terhadap pemasaran hasil perikanan dan tidak jarang juga menimbulkan kerugian terutama pada saat produksi ikan yang berlimpah sebab jika ikan sudah busuk atau sudah tidak layak untuk dikonsumsi maka ikan akan terbuang secara percuma dan menyebabkan kerugian yang besar terhadap pemasaran hasil perikanan sehingga melihat kondisi permasalahan tersebut perlu adanya penanganan yang tepat, cepat, benar dan baik untuk menjaga kualitas ikan mujair sebelum dipasarkan dan sampai ke tangan konsumen maka perlu adanya proses pengawetan untuk memperpanjang masa simpan ikan [2].

Berdasarkan Peraturan Menteri Kesehatan No. 1168/MENKES/PER/X/1999 bahan tambahan yang diperbolehkan untuk digunakan sebagai pengawet makanan adalah garam atau $\mathrm{NaCl}$, sodium tripolyphosphat (STPP), gula pasir, sodium nitrit, sodium laktat, sodium asetat, dan berbagai senyawa seperti kalium nitrat, kalsium nitrat, natrium nitrat. Masyarakat pada umumnya tidak menggunakan bahan-bahan tersebut karena selain harganya cukup mahal, masyarakat juga kuatir akan merubah cita rasa dari bahan yang akan diawetkan. Masyarakat lebih memilih menggunakan pengawet sintetik yang dilarang penggunaannya yaitu pengawet formalin. Pengawet formalin merupakan bahan yang dapat mengakibatkan penyakit kanker apabila sering dikonsumsi [3].

Pangi (Pangium edule Reinw) adalah nama lain untuk tanaman Picung atau kluwek yang banyak tumbuh di daerah Minahasa, Sulawesi Utara. Biji pangi mengandung senyawa antioksidan yang berfungsi sebagai senyawa anti kanker antara lain asam askorbat atau vitamin $\mathrm{C}$, ion besi, $\beta$-karoten dan senyawa golongan flavonoid yang berfungsi sebagai anti-bakteri diantaranya asam sianida, asam hidrokarpat, asam khaulmograt, asam gorlat dan tannin [4].

Penggunaan biji pangi dapat dijadikan sebagai pengawet karena banyak mengandung tanin yang merupakan senyawa polifenol alami. Senyawa fenolik yang dapat menghambat pertumbuhan mikroba melalui permeabilitas dinding selnya [5]. data penelitian Senyawa kimia ini efektif dalam mengendalikan perkembangbiakan bakteri pada ikan dan daging, seperti bakteri Pseudomonas aeruginosa, Escherichia coli dan Staphylococcus aureus [6]. Tujuan penelitian ini adalah untuk menguji potensi ekstrak biji pangi sebagai pengawet alami ikan mujair, mengetahui lamanya daya simpan ikan mujair pada proses pengawetan ikan mujair menggunakan ekstrak biji pangi dan mengetahui konsentrasi yang tepat dalam proses pengawetan ikan mujair, mengetahui tingkat toksik ekstrak biji pangi sebelum digunakan sebagai pengawet.

\section{Bahan dan Metode}

Sampel berupa biji pangi (Pangium edule Reinw.) diambil dari kebun kampus Universitas Negeri Manado, ikan mujair segar, aquades, besi (III) klorida (Merck), asam klorida (Merck), natrium hidroksida (Merck), kalium iodida (Merck), methanol (Merck), ethanol PA (Merck), ninhidrin (Merck), natrium karbonat (Merck), dan etanol 70\%, garam, $30 \mathrm{~g}$ Artemia golden supreme, asam sulfat, indikator fenolftalein, dan selenium. Penelitian ini merupakan penelitian eksperimen dengan melibatkan dua parameter mutu ikan yaitu parameter kerusakan fisik dan parameter kerusakan kimia.

\section{Pembuatan Ekstrak Biji pangi}

Ekstrak biji pangi dibuat dengan cara maserasi mengacu pada Makagansa et al. (2015) [7]. Buah pangi dengan panjang $\pm 17 \mathrm{~cm}$ dipisahkan dari bijinya, kemudian biji pangi tersebut direbus sampai mendidih sehingga buah bijinya dapat dipisahkan dari batok buah yang keras, daging biji kemudian dicincang dengan ukuran kurang lebih $2 \mathrm{~cm}$ dan 
dimasukkan dalam karung terigu dan direndam dalam air yang mengalir selama tiga hari untuk menghilangkan kandungan asam sianida. Biji pangi yang telah direndam dicuci bersih dengan air mengalir dan digerus halus, kemudian biji yang telah dihaluskan dikeringkan selama tiga hari sehingga didapatkan serbuk biji pangi yang telah kering. Sampel berupa serbuk kering dihaluskan menggunakan blender. Simplisia biji pangi sebanyak $5 \mathrm{~kg}$ selanjutnya diekstraksi dengan menggunakan metode maserasi, serbuk simplisia dimasukkan kedalam toples kaca dan direndam dengan etanol $70 \%$ sebanyak $20 \mathrm{~L}$ dan diaduk kemudian ditutup serta direndam selama 1 x 24 jam, Ekstrak disaring untuk memisahkan filtrat dan ampasnya, kemudian dievaporasi menggunakan rotary evaporator hingga didapatkan ekstrak biji pangi dalam bentuk liquid

\section{Identifikasi Sianida}

Sebelum ekstrak biji pangi digunakan sebagai pengawet ikan mujair terlebih dahulu dilakukan identifikasi sianida dengan menggunakan berbagai pereaksi uji yaitu menggunakan AgNO3 0,1 N, besi (III) klorida $1 \% \mathrm{~b} / \mathrm{v}$, asam klorida $0,1 \mathrm{~N}$, kalium iodida 0,1 $\mathrm{N}$, natrium hidroksida $0,1 \mathrm{~N}$. Berbagai pereaksi tersebut dilarutkan ke dalam sampel ekstrak biji pangi dan didiamkan selama 5 menit selanjutnya diamati perubahan warna yang terjadi.

Uji Sitotoksik

Uji toksisitas pada ekstrak biji pangi dilakukan dengan menggunakan larva Artemia salina sebanyak $2 \mathrm{sdm}$. Penetasan dilakukan dengan cara meredam larva tersebut dalam air garam sebanyak $500 \mathrm{ml}$ serta diaerasi selama 48 jam. Air laut dibuat dengan cara melarutkan 2 sdm garam dalam $500 \mathrm{ml}$ air kemudian di homogenasi. Pembuatan larutan uji dibuat dengan konsentrasi 2000 ppm pada tabung reaksi. Pembuatan stok di lakukan dengan cara 20 mg sampel ekstrak biji pangi di larutkan ke dalam $10 \mathrm{ml}$ air laut, selanjutnya di homogenasi dengan vortex. Hasil dari larutan stok seelanjutnya dibuat dengan konsentrasi $1000 \mu \mathrm{l}$, $500 \mu \mathrm{l}, 100 \mu \mathrm{l}, 10 \mu \mathrm{l}$ stok sampel selanjutnya tambahkan $1000 \mu \mathrm{l}$ air garam di setiap konsentrasi, kemudian masukkan 10 ekor larva udang yang telah berumur 2 hari. Setiap konsentrasi dilakukan 3 kali ulangan. Pengamatan jumlah larva yang mati di hitung setelah 24 jam. Nilai LC50 dengan memasukkan angka probit [8].

\section{Perlakuan sampel terhadap ikan mujair}

Hasil ekstrak biji pangi dilumurkan pada ikan yang telah dibersihkan isi perutnya. Pembuatan konsentrasi ekstrak yaitu konsentrasi $5 \%$ yaitu 5 gram ekstrak biji pangi dilarutkan dengan aquades hingga $100 \mathrm{~mL}$ dilakukan sebanyak 3 ulangan dan konsentrasi $10 \%$ yaitu 10 gram ekstrak biji pangi dilarutkan hingga $100 \mathrm{~mL}$ dilakukan sebanyak 3 ulangan kemudian dikemas dalam wadah plastik bertutup, yang pengukuran di lakukan pada hari ke 0. 2. 4, dan dilakukan penyimpanan pada suhu kamar [9].

\section{Uji Protein}

Parameter untuk mendeteksi kerusakan ikan mujair selama penyimpanan pada suhu kamar menggunakan uji protein. Ikan yang digunakan hanya salah satu perwakilan setiap ulangan pada hari ke-0, 2 dan 4 dengan metode menggunakan Metode Kjeldahl. Sampel ikan mujair dikumpulkan, dikelompokkan dan dicuci dengan air bersih selanjutnya daging mujair lalu di potong-potong kecil kemudian di masukkan ke dalam wadah, $\mathrm{NaOH}$ ditimbang sebanyak 30 gram, kemudian dimasukkan ke dalam Erlenmeyer $250 \mathrm{ml}$, lalu dilarutkan dengan aquadest hingga $100 \mathrm{ml}$ dan dikocok hingga homogen. $\mathrm{NaOH}$ ditimbang sebanyak 2 gram, kemudian dimasukkan ke dalam labu ukur $500 \mathrm{ml}$, lalu dilarutkan dengan aquadest hingga batas tanda dan dikocok hingga homogen. Diukur $\mathrm{HCl}$ pekat sebanyak 4,17 ml, isi labu ukur $500 \mathrm{ml}$ dengan aquadest sebanyak $250 \mathrm{ml}$ lalu tambahkan 4,17 $\mathrm{ml} \mathrm{HCl}$ secara perlahan, cukupkan volumenya dengan aquadest sampai batas tanda kemudian dikocok hingga homogen lalu dimasukan ke dalam wadah tertutup rapat dan terlindung dari cahaya. Methil orange ditimbang sebanyak 1 gram, kemudian dilarutkan dengan $100 \mathrm{ml}$ etanol, setelah larut kemudian ditambahkan aquadest $100 \mathrm{ml}$ dan kocok hingga homogen atau saring jika perlu. Timbang seksama $0,2 \mathrm{~g}$ kalium biftalat kemudian larutkan dengan 10 
$\mathrm{ml}$ aquadest bebas $\mathrm{CO}_{2}$ kemudian tambahkan 2 tetes indikator fenolftalein kemudian, titrasi dengan $\mathrm{NaOH}$ 0,1 $\mathrm{N}$ hingga warna merah jambu. Sampel ditimbang \pm 1 gram kemudian dimasukkan ke dalam labu kjeldahl ditambahkan $15 \mathrm{ml} \mathrm{H}_{2} \mathrm{SO}_{4}$ pekat dan 2 gram selenium, lalu didestruksi selama 3 sampai 5 jam. Proses destruksi sempurna setelah larutan menjadi jernih kemudian didinginkan. Hasil destruksi diencerkan dengan air suling sebanyak $100 \mathrm{ml}$ lalu ditambahkan $50 \mathrm{ml} \mathrm{NaOH}$ $30 \%$ secara perlahan-lahan, selanjutnya dilakukan destilasi. Destilasi ditampung ke dalam labu Erlenmeyer $250 \mathrm{ml}$ yang berisi $50 \mathrm{ml}$ larutan $\mathrm{KCl}$ 0,1 N. Proses destilasi selesai jika destilat yang ditampung lebih kurang $75 \mathrm{ml}$. Sisa larutan $\mathrm{HCl}$ 0,1 N yang tidak bereaksi dengan destilat, ditambahkan Methil orange sebanyak 2 tetes lalu dititrasi dengan larutan baku $\mathrm{NaOH}$ 0,1 N. Titik akhir titrasi ditandai dengan munculnya warna merah muda yang pertama dan tetap selama 30 detik. Dilakukan titrasi blanko dengan perlakuan yang sama tanpa menggunakan sampel [1]. Data yang diambil berupa hasil penentuan kadar protein dari masing-masing perlakuan dengan menghitung kadar nitrogen total (persamaan 1) dan kadar nitrogen bukan protein dengan menggunakan persamaan 2 [10]. Dimana, $\mathrm{Vb}$ adalah Volume titrasi blanko (ml), Vs adalah volume titrasi sampel $(\mathrm{ml}), \mathrm{N}$ adalah normalitas $\mathrm{NaOH}$ baku dan Fk adalah faktor konversi 6,25.

$$
\begin{aligned}
& N \%=\frac{(\mathrm{Vb}-\mathrm{Vs})}{\text { berat sampel }(\mathrm{mg})} \times \mathrm{N} \mathrm{NaOH} \times 14,008 \times \\
& 100 \%
\end{aligned}
$$

Kadar protein $=\% \mathrm{~N} \times$ Faktor konversi

Uji $p H$

Uji pH ikan dilakukan dengan menggunakan indikator $\mathrm{pH}$ (kertas lakmus). Celupkan kertas indicator $\mathrm{pH}$ bagian berwarna ke dalam sampel diamkan beberapa menit kemudian lihat perubahan warna. Perubahan warna bandingkan dengan warna pada kotak indikator $\mathrm{pH}$, cocokkan warna yang paling sesuai dengan warna indikator $\mathrm{pH}$, lihat angka yang tertera pada ujung warna. Uji $\mathrm{pH}$ dilakukan terhadap 9 ekor ikan dan dilakukan pada hari ke-0, 2 dan 4.

\section{Hasil dan Pembahasan}

Ekstraksi Biji Pangi

Hasil ekstraksi dari $5 \mathrm{~kg}$ simplisia biji pangi dalam etanol berupa filtrat berwarna kuning. Setelah diuapkan menggunakan rotary evaporator menghasilkan ekstrak kental sebanyak 45 gram ekstrak yang berwarna coklat sehingga rendemen yang dihasilkan dari ekstraksi menggunakan pelarut etanol sebesar $0.9 \%$.

Tabel 1. Hasil uji sianida dengan berbagai

\begin{tabular}{|c|c|c|c|}
\hline No & Pereaksi & $\begin{array}{c}\text { Pengamata } \\
\mathrm{n}\end{array}$ & Hasil \\
\hline 1. & $\begin{array}{l}\text { Akuades } \\
\text { (kontrol) }\end{array}$ & Coklat & - \\
\hline 2. & AgNO3 0,1 N & Coklat & $\begin{array}{c}(-) \\
\mathrm{HCN}\end{array}$ \\
\hline 3. & $\begin{array}{c}\text { Besi (III) Klorida } \\
1 \% \mathrm{~b} / \mathrm{v}\end{array}$ & Coklat & $\begin{array}{c}(-) \\
\mathrm{HCN}\end{array}$ \\
\hline 4. & $\begin{array}{c}\text { Asam Klorida } 0,1 \\
\mathrm{~N}\end{array}$ & Coklat & $\begin{array}{c}(-) \\
\mathrm{HCN}\end{array}$ \\
\hline 5. & $\begin{array}{c}\text { Kalium Iodida } \\
0,1 \mathrm{~N}\end{array}$ & Coklat & $\begin{array}{c}(-) \\
\mathrm{HCN}\end{array}$ \\
\hline 6. & $\begin{array}{c}\text { Natrium } \\
\text { Hidroksida } 0,1 \mathrm{~N}\end{array}$ & Coklat & $\begin{array}{c}(-) \\
\mathrm{HCN}\end{array}$ \\
\hline
\end{tabular}
pereaksi

\section{Identifikasi Sianida}

Hasil uji sianida pada ekstrak biji pangi dapat dilihat pada Tabel 1. Penambahan pereaksi uji sianida terhadap ekstrak biji pangi tidak mengalami perubahan warna dan tidak terdapat endapan. Hal ini menunujukkan bahwa sampel ekstrak biji pangi sudah tidak ada kandungan sianida sehingga ekstrak biji pangi selanjutnya bisa digunakan sebagai pengawet [11]. Pada penelitian uji sianida pada ekstrak pohon untuk mengetahui kadar sianida dalam sampel alami dilakukan dengan cara membandingan warna larutan dengan larutan kontrol jika terjadi perubahan warna dan tidak ada endapan hal itu menunjukkan adanya kandungan sianida dan sebaliknya jika sampel berubah warna dan terdapat endapan maka sampel itu menunjukkan adanya kandungan sianida [12]. Hasil penelitian menunjukkan bahwa kadar sianida dalam kluwek atau pangi mentah sebesar $3,3010 \pm 1,0110 \mathrm{mg} / \mathrm{g}$, penurunan kadar sianida dalam kluwek mentah atau pangi setelah perlakuan dengan 
perebusan selama satu jam yaitu 79,73\% sedangkan penurunan kadar sianida dalam kluwek atau pangi setelah diperam selama 10, 20, 30, 40 dan 50 hari berturut-turut sebanyak $83,78 \%$; $90,53 \%$ 96,72\%; $98,64 \%$ dan $99,03 \%$ [13].

Uji toksisitas Brine Shrimp Lethality Test (BSLT)

Hasil analisis probit dengan menggunakan Microsoft Excel menunjukkan nilai LC $_{50}$ dari ekstrak biji pangi adalah 19.952 ppm (tabel 2). Suatu ekstrak menunjukkan aktivitas ketoksikan dalam uji toksisitas jika ekstrak dapat menyebabkan kematian 50\% hewan uji pada konsentrasi < $1000 \mathrm{ppm}$ dan tingkat toksisitas suatu ekstrak adalah sebagai berikut : $\mathrm{LC}_{50} \leq 30 \mathrm{mg} / \mathrm{L}=$ sangat toksik; $\mathrm{LC}_{50} \leq 1.000 \mathrm{mg} / \mathrm{L}$ $=$ toksik; $\mathrm{LC}_{50}>1.000 \mathrm{mg} / \mathrm{L}=$ tidak toksik [14-16]. Berdasarkan dari pernyataan tersebut maka ekstrak biji pangi tidak bersifat toksik. Hal ini ditunjukan dari nilai $\mathrm{LC}_{50}$ yang diperoleh pada konsentrasi $19.952 \mathrm{mg} / \mathrm{L}$.

Tabel 2. Hasil Pengujian BSLT

\begin{tabular}{|c|c|c|c|c|c|}
\hline $\begin{array}{c}\text { Konsen- } \\
\text { trasi } \\
(\mathrm{mg} / \mathrm{L})\end{array}$ & $\begin{array}{c}\text { Kon } \\
\text { sen- } \\
\text { trasi } \\
\text { Log } \\
10\end{array}$ & $\begin{array}{c}\text { Tota } \\
1 \\
\text { Larv } \\
\text { a }\end{array}$ & $\begin{array}{c}\text { Lar } \\
\text { va } \\
\text { Mat } \\
\text { i }\end{array}$ & $\begin{array}{c}\% \\
\text { Mort } \\
\text { a- } \\
\text { litas }\end{array}$ & $\begin{array}{c}\text { Nila } \\
\text { i } \\
\text { Prob } \\
\text { it }\end{array}$ \\
\hline 0 & 0 & 10 & 0 & $0 \%$ & 0 \\
\hline 10 & 1.0 & 10 & 0 & $0 \%$ & 0 \\
\hline 100 & 2.0 & 10 & 2 & $7 \%$ & 3.52 \\
\hline 500 & 2.7 & 10 & 3 & $10 \%$ & 3.72 \\
\hline 1000 & 3.0 & 10 & 5 & $17 \%$ & 4.05 \\
\hline \multicolumn{5}{|c|}{$\mathrm{LC}_{50}(\mathrm{ppm})$} & $\begin{array}{c}19.95 \\
2\end{array}$ \\
\hline
\end{tabular}

Uji Kerusakan Ikan Mujair

Analisis Kandungan Protein pada Ikan Mujair

Analisis kandungan protein pada ikan mujair segar dengan metode kjehdahl menunjukkan bahwa perlakuan pengawet dengan menggunakan biji pangi pada kontrol, ekstrak biji pangi dengan konsentrasi 5\% dan konsentrasi $10 \%$ di hari ke-0 (3 jam) ikan masih dalam keadaan segar dengan kadar protein pada ikan masih tergolong tinggi yaitu pada kontrol sebesar 9,68\%, pada konsentrasi $5 \%$ dengan kadar protein $8,81 \%$ dan pada konsentrasi $10 \%$ dengan kadar protein $10 \%$. Pada hari ke-2 kadar ikan protein mengalami penurunan. Kadar protein ikan mujair yang diredam dengan ekstrak biji pangi pada konsentrasi $5 \%$ dan $10 \%$ berkisar $7,68 \%$ dan 9,31\% tidak menurun secara signifikan dan pada kontrol ikan mujair membusuk dan tidak bisa dilakukan pengujian kadar protein. Pada hari ke-4 kadar protein ikan mujair pada perlakuan $5 \%$ dan $10 \%$ dengan ekstrak biji pangi mengalami penurunan 5,31\% dan 6,43\%, dengan kadar protein sebesar ini masih tergolong ikan dengan kadar protein yang cukup baik sehingga ekstrak biji pangi memiliki pengaruh nyata sebagai salah satu alternatif yang dapat digunakan sebagai pengawet pada ikan.

Pengujian kadar protein pada ikan mujair menunjukkan adanya perbedaan kadar protein pada hari ke-0, 2, 4. Kandungan protein ikan semakin menurun seiring penambahan waktu karena adanya proses degradasi protein yang membentuk berbagai produk seperti hipoksantin, trimetilamin, dan terjadinya proses ketengikan oksidatif dan pertumbuhan mikroorganisme [9]. Kebusukan ikan mulai terjadi setelah proses rigor mortis selesai. Faktor yang menyebabkan ikan cepat membusuk adalah kadar glikogennya yang rendah sehingga proses rigor mortis berlangsung lebih cepat dan $\mathrm{pH}$ akhir daging ikan cukup tinggi yaitu 6,4 -6,6, serta tingginya jumlah bakteri yang terkandung di dalam perut ikan. Bakteri proteolitik mudah tumbuh pada ikan segar dan menyebabkan bau busuk hasil metabolisme protein $[7,10,17,18]$.

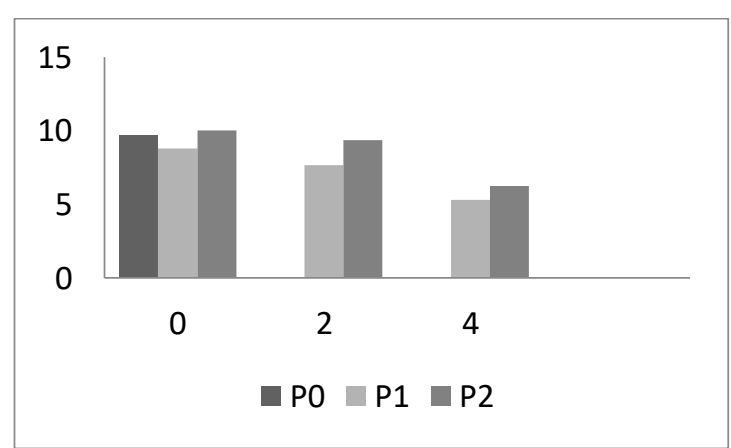

Gambar 1. Hasil Analisis Kandungan Protein pada Ikan Mujair. P0 : konsentrasi 0\%; P1 :

konsentrasi 5\%; P2 : konsentrasi 10\%

Uji $p H$

Nilai $\mathrm{pH}$ merupakan salah satu parameter yang dapat digunakan untuk mengetahui 
kesegaran dari hasil perikanan. Dimana A1B1= Lama penyimpanan 0 hari (konsentrasi $0 \%$ ); A1B2= Lama penyimpanan 2 hari (konsentrasi $0 \%)$ A1B3= Lama penyimpanan 4 hari (konsentrasi 0\%); A2B1= Lama penyimpanan 0 hari (konsentrasi 5\%); $\mathrm{A} 2 \mathrm{~B} 2=\quad$ Lama penyimpanan 2 hari (konsentrasi 5\%); $\mathrm{A} 2 \mathrm{~B} 3=$ Lama penyimpanan 4 hari (konsentrasi $5 \%$ ); A3B1 = Lama penyimpanan 0 hari (konsentrasi $10 \%) ; \mathrm{A} 3 \mathrm{~B} 2=$ Lama penyimpanan 2 hari (konsentrasi 10\%); A3B3= Lama penyimpanan 4 hari (konsentrasi 10\%). Dari hasil tabel 4 menunjukkan bahwa semakin kecil konsentrasi ekstrak biji pangi pada penelitian ini maka semakin besar nilai $\mathrm{pH}$ ikan mujair. $\mathrm{pH}$ yang ikan dari hari 0 hingga hari ke-4 mengalami kenaikan $\mathrm{pH}$ dari dibawah netral hingga $\mathrm{pH}$ mendekati netral. Nilai $\mathrm{pH}$ untuk ikan hidup sekitar 7,0 dan setelah ikan mati $\mathrm{pH}$ ikan tersebut menurun mencapai 5,8-6,2 [19]. Dari tabel 4 menunjukkan bahwa nilai $\mathrm{pH}$ rata-rata sebelum selama penyimpanan berada pada kisaran asam menuju $\mathrm{pH}$ netral yang artinya $\mathrm{pH}$ ikan semakin bagus dan konsentrasi 5\% merupakan konsentrasi yang paling berpengaruh nyata terhadap nilai $\mathrm{pH}$.

Hasil statistik menggunakan uji two ways ANOVA pH ikan mujair yang diawetkan dengan ekstrak biji pangi terdapat perbedaan nyata $(\mathrm{P}<0,05)$. Uji beda nyata menunjukkan bahwa lama penyimpanan ikan dan pemberian perlakuan konsentrasi berpengaruh nyata $(\mathrm{P}<0,05)$ pada uji $\mathrm{pH}$.

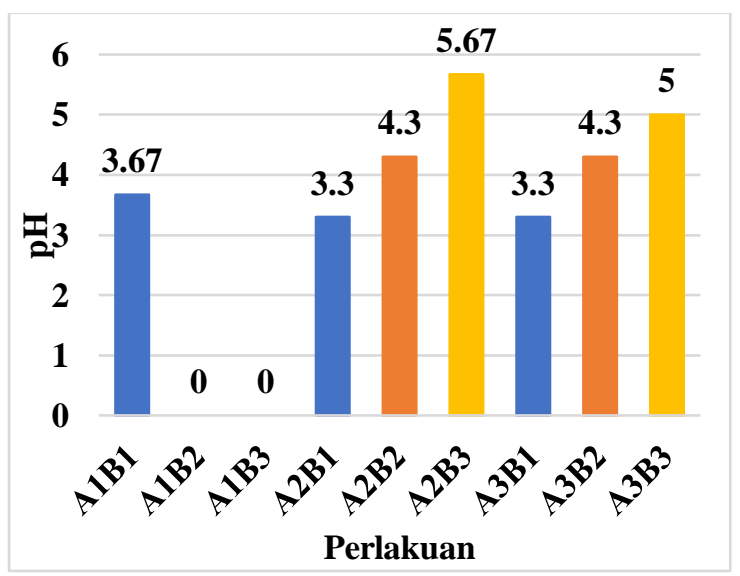

Gambar 2. Hasil analisis uji pH

\section{Kesimpulan}

Dari hasil penelitian disimpulkan bahwa ekstrak biji pangi dapat berpotensi sebagai pengawet alami ikan mujair dimana lama pengawetan menggunakan ekstrak biji pangi dapat mengawetkan ikan mujair selama 4 hari dengan konsentrasi yang optimal untuk pengawetan ikan mujair menggunakan ekstrak biji pangi pada konsentrasi $10 \%$ sedangkan untuk $\mathrm{pH}$ ikan konsentrasi yang paling optimal adalah konsentrasi 5\%.

\section{Daftar Pustaka}

1. Abdul, R.S.; Sumantri Analisis Makanan; Gadjah Mada University Press: Yogyakarta, 2007;

2. Liviawaty, E.; Afrianto, E. Penanganan Ikan Segar; Widya Padjadjaran: Bandung, 2010;

3. Asriningrum Kajian Penambahan Nacl Dan Tepung Tapioka Pada Pembuatan Kamaboko Ikan Mujair, Universitas Pembangunan Nasional "Veteran": Jawa Timur.

4. Chye, F.Y.; Sim, K.Y. Antioxidative and antibacterial activities of Pangium edule seed extracts. Int J Pharmacol 2009, 5, 285297.

5. Warnasih, S.; Hasanah, U. Phytochemical Characterization and Tannin Stability Test From Kluwek (Pangium Edule Reinw). Journal of Science Innovare 2019, 1, 44-49.

6. Mamuaja, C.F.; Lumoindong, F. Aktivitas antimikroba ekstrak biji kluwek (Pangium edule) sebagai bahan pengawet alami bakso ikan tuna. Jurnal Pengolahan Hasil Perikanan Indonesia 2017, 20, 592601.

7. Makagansa, C.; Mamuaja, C.F.; Mandey, L.C. The Antibacterial Activity of Pangi Kernel Extract (Pangium edule Reinw) towards Staphylococcus aureus, Bacillus cereus, Pseudomonas aeruginosa and Escherichia coli in Vitro. Jurnal Ilmu dan Teknologi Pangan 2015, 3.

8. Aloanis, A.A.; Fahriana, F.; Haryadi, H. Skrining fitokimia dan uji toksisitas ekstrak daun balik angin (Mallotus Sp) terhadap larva Artemia salina Leach dengan metode brine shrimp lethality test (BSLT). Fullerene Journal of Chemistry 2017, 2, 77-81.

9. Josef, I.R.; Kapahang, A.; Gumolung, D. Penghambatan Oksidasi Lipid Minyak Ikan Cakalang (Katsuwonus pelamis) Oleh Air Jahe (Zingiber officinale var. rubrum) 
Selama Penyimpanan Dingin. Fullerene Journal of Chemistry 2019, 4, 66-71.

10. Syafruddin, S.; Hasan, H.; Amin, F. Analisis Kadar Protein pada Ikan Lele (Clarias Batrachus) yang Beredar di Pasar Tradisional di Kabupaten Gowa dengan Menggunakan Metode Kjeldahl. Majalah Farmasi Nasional 2016, 13, 77-87.

11. Samudry, E.G.; Sukainah, A.; Mustarin, A. Analisis Kualitas Kluwek (Pangium Edule Reinw) Hasil Fermentasi Menggunakan Media Tanah dan Abu Sekam. Jurnal Pendidikan Teknologi Pertanian 2018, 3, 2533.

12. Sulistyarti, H.; Kusumawardhani, N.; Zulfah, N.L.; Cahyani, Y.D.; Fahriyani, H.E.; Milda, B. Test Kit untuk Analisis Sianida dalam Ketela Pohon Berdasarkan Pembentukan Hidrindantin. In Proceedings of the Pekan Ilmiah Mahasiswa Nasional Program Kreativitas Mahasiswa-Penelitian 2014; Indonesian Ministry of Research, Technology and Higher Education, 2014.

13. Nurfaida, F. Analisis penurunan kadar sianida dalam kluwek hasil pemeraman biji picung (Pangium edule Reinw.), Universitas Negeri Malang, 2012.

14. Sangi, M.S.; Momuat, L.I.; Kumaunang, M. Uji toksisitas dan skrining fitokimia tepung gabah pelepah aren (Arenga pinnata). Jurnal Ilmiah Sains 2012, 12, 127-134.

15. Sumihe, G.; Runtuwene, M.R.; Rorong, J.A. Analisis Fitokimia dan Penentuan Nilai LC50 Ekstrak Metanol Daun Liwas. Jurnal Ilmiah Sains 2014, 14, 125-128.

16. Hamrun, N.; Nabilah, T.; Hasyim, R.; Ruslin, M.; Dammar, I.; As, M.A. Toxicity Test of Bioactive Red Alga Extract Eucheuma spinosum on Shrimp Artemia Salina Leach. Systematic Reviews in Pharmacy 2020, 11, 672-676.

17. Patriani, P.; Hafid, H.; Mirwandhono, E.; Wahyuni, T.H.; Hasanah, U.; Apsari, N.L.; Ginting, N. Physical quality characteristics of lamb meat using Pangium edule extract at different storage times. EEES 2020, 454, 012056.

18. Munandar, A.; Indaryanto, F.R.; Prestisia, H.N.; Muhdani, N. Potensi Ekstrak Daun Picung (Pangium edule) sebagai Bahan
Pemingsan Ikan Nila (Oreochromis niloticus) pada Transportasi Sistem Kering. Jurnal FishtecH 2017, 6, 107-114.

19. Ilyas S Teknologi Refrigerasi Hasil Perikanan; Jilid 2.; CV Paripurna: Jakarta;1983

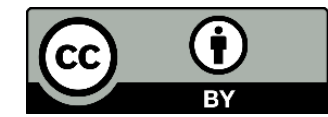

(C) 2020 by the authors. Licensee Fullerene Journal Of Chem. This article is an open access article distributed under the terms and conditions of the Creative Commons Attribution (CC BY) license

(http://creativecommons.org/licenses/by/4.0/). 